DOI: $10.17516 / 1997-1370-0752$

УДК 378

\title{
Challenges and Solutions in the Development of Professional Social Work in Vietnam \\ in International Integration: Vision and Orientation
}

\section{Luong Manh Ha*}

Tan Trao University

Tuyen Quang, Vietnam

Received 09.04.2020, received in revised form 20.04.2021, accepted 28.04.2021

\begin{abstract}
The growth of professional social work in Vietnam took a major step forward in 2004, that social work was officially recognized as a profession in Vietnam when the Vietnam Prime Minister approved Decree 32 about Developing Social Work Profession in Vietnam, a national master blueprint to develop social work. This article gives an overview of current challenges and solutions that are being implemented to address the major issues that Vietnam is facing. Especially, the Vision and Orientation to development of Professional Social Work in Vietnam in international integration. Besides that also refers to aims at providing suggestions for maintaining the social work education in Vietnam with professional training direction.
\end{abstract}

Keywords: Social Workers, Social development, Social Work Vietnam, vision development, challenges and solutions.

This research is funded by Tan Trao University, Vietnam. The authors declare that they have no conflicts of interest.

Research area: law.

Citation: Luong Manh Ha (2021). Challenges and solutions in the development of professional social work in Vietnam in international integration: vision and orientation. J. Sib. Fed. Univ. Humanit. Soc. Sci., 14(5), 693-701. DOI: 10.17516/1997-1370-0752.

(C) Siberian Federal University. All rights reserved

* Corresponding author E-mail address: ha.cdtq@gmail.com 


\title{
Вызовы и решения в развитии профессиональной социальной работы во Вьетнаме в международной интеграции: видение и ориентация
}

\author{
Лыонг Мань Ха \\ Тан Трао университет \\ Вьетнам, Туйен Куанг
}

\begin{abstract}
Аннотация. Рост профессиональной социальной работы во Вьетнаме сделал большой шаг вперед в 2004 году. Социальная работа была официально признана профессией во Вьетнаме, когда премьер-министр утвердил Указ 32 о развитии профессии социального работника во Вьетнаме, который является национальным основным проектом развития социальной работы. В статье дан обзор текущих проблем и решений, которые применяются для урегулирования основных вопросов, стоящих перед Вьетнамом. В частности, видение и ориентация на развитие профессиональной социальной работы во Вьетнаме в условиях международной интеграции.
\end{abstract}

Ключевые слова: социальные работники, социальное развитие, социальная работа, Вьетнам, развитие видения, вызовы и решения.

Это исследование финансируется университетом Тан Трао, Вьетнам. Авторы заявляют об отсутствии конфликта интересов.

Научная специальность: 12.00 .00 - юридические науки.

\section{Introduction}

To progress effectively, minimize wasted efforts and avoid detours a developing profession should be founded on a distinct vision. In the case of the emerging profession of social work in developing countries such as Vietnam, there is a need to have a shared vision and orientation.

Firstly, this shared vision and orientation can enhance consistency in accomplishing a wide range of foundational activities such as building governmental laws and policies, establishing educational standards and codes of ethics, creating national and local service delivery systems, and promoting common discourse about social work within the public.

Secondly, this shared vision and orientation can help in resisting wholesale "the dominance of the Western paradigm" and in developing a truly indigenous profession, that fits the Vietnamese context and serves Vietnamese people (Brydon \& Lawihin, 2016: 192). The lat- ter has become increasingly significant because contemporary Vietnam is unique in its position as one of the only remaining communist countries in the world, a market economy but culturally embedded in Confucianism, Taoism, Buddhism, and local beliefs. Many developed countries with longer histories of formal social work systems of care provide important lessons and models relevant in their contexts. However, Vietnam must be cognizant of the complex issues raised by global debates regarding "globalization versus localization, Westernization versus indigenization, multiculturalism versus universalism, and universal versus local standards" in developing the social work system of policy and practice (Brydon \& Lawihin, 2016: 192).

While social work has a long history of development in Western countries, it is still a new profession in Vietnam. The Government and the related ministries and organizations in Vietnam were very active in developing ini- 
tiatives and plans for promoting social work nationwide. The strategies for social work development from 2010-2020, the decision on employment code for social workers and support workers, the establishment of social worker network, annual workshops on social work are the specific examples of the prospects for social work development in the future. At this early stage, social work in Vietnam has been facing many challenges: from awareness of this professional job to the lack of learning materials, practicum places, staff and skills on supervisions as well as the teaching staff on social work (Hugman, Lan \& Hong, 2009). However, in the era of critical social development strategy and welfare reform, social work also gets significant social concerns and opportunities for its development professionally. In these strategies, it is proposed that the number of people in a section of welfare service can be increased and required more professional services and support. Vietnam is trying to build the welfare system, which is based on:

1) Welfare rights in specific social and economic conditions;

2) The welfare coverage for all individuals with diversity solutions;

3) The specific concerns for the vulnerable groups such as the poor, the disabled people, ethnic groups, the unemployed, the older persons, the migrants, and victims of natural disasters;

4) empowered approach in aspects of indirect support to sustainable development;

5) the role of the State on administrating as well as the role of the social organizations in practice which widens the number of stakeholders on this welfare reform (Viện KHLĐXH, 2010).

\section{Background: Social Work in Vietnam}

Following a long history with a rich tradition of community- and family-based altruism, Vietnam began developing its social work profession only recently. For hundreds of years, families and local communities were primary sources of support for people in need of help (Oanh, 2002). Tens of thousands of Buddhist temples embedded in every village also played a significant role in providing food, shelter, counseling, and spiritual support for individuals, families, and whole communities (Nguyen, 2014) (Table 1).

In modern times, between the end of the Vietnam War and the early 2000s, service provision remained primarily informal. Formal social services were provided only for the very poor or those severely physically and mentally affected by the war. It was not until 2010 that the term "social work" was re-introduced into national public discourse when the Vietnam Prime Minister approved Decree 32 about Developing Social Work Profession in Vietnam (Oanh, 2002; Nguyen, 2009; Nguyen, 2014).

The central government of Vietnam, especially the Ministry of Labor, Invalids, and Social Affairs (MOLISA) under the direction by the Prime Minister, has been playing the leading role in the development of Vietnamese social work. This charge to MOLISA includes developing a Code of Ethics, practice standards, licensure, and employment and salary standards for social workers. Working in tandem with MOLISA, the Ministry of Education and Training (MOET) is in charge of developing curriculum requirements and accreditations. The Ministry of Health $(\mathrm{MOH})$ is in charge of issues related to the intersection between social work and health; and the Ministry of Internal Affairs is responsible for creating job titles and salary standards for social work professionals for the existing governmental job system (Huong Nguyen, Trang Thu Nguyen \& Naomi Farber, 2017).

\section{Challenges in Developing Professional \\ Social Work and Strategic Solutions of the Vietnamese Government in International Integration}

International integration is an indispensable trend and is increasingly being extended to many countries and territories, including Vietnam. In addition to good opportunities for comprehensive development of the country, international integration has created challenges for Vietnam in all sectors. In which, there are great challenges to developing professional social work both in the short and long term, directly or indirectly, such as: challenges in the 
Table 1. Summarizes the key milestones in the history of Vietnamese social work

\begin{tabular}{|c|c|}
\hline $\begin{array}{l}\text { Pre-French colonial time } \\
\text { (pre-1862) } \\
\text { - Nguyen Dynasty }\end{array}$ & $\begin{array}{l}\text { Nguyen dynasty issued Dai Nam Thuc Luc Chinh Bien, specifying welfare for the } \\
\text { weak, the sick, and the dead }\end{array}$ \\
\hline $\begin{array}{l}\text { French colonial period } \\
(1862-1945)\end{array}$ & $\begin{array}{l}\text { Institutions established for orphans, elderly, the handicapped, prostitutes and ju- } \\
\text { venile delinquents by the French colonial government and Catholic missionaries }\end{array}$ \\
\hline $\begin{array}{l}\text { Post-French colonial period } \\
(1945-1954)\end{array}$ & $\begin{array}{l}\text { Caritas School of Social Work established by the French Red Cross in Southern } \\
\text { Vietnam. }\end{array}$ \\
\hline 1947 & Vietnam \\
\hline $\begin{array}{l}\text { Vietnam War } \\
(1954-1975)\end{array}$ & \\
\hline 1955 & $\begin{array}{l}\text { - Settlements and reliefs for Catholic refugees from Northern Vietnam estab- } \\
\text { lished by American NGOs. Child welfare and social welfare in Southern Vietnam } \\
\text { supported by the U.S. }\end{array}$ \\
\hline 1957 & $\begin{array}{l}\text { - The Vietnam Army School of Social Work and the Buddhist Youth School for } \\
\text { Social Service established in Saigon. }\end{array}$ \\
\hline 1968 & $\begin{array}{l}\text { - The National Association of Schools of Social Work (NASSW) founded by Viet- } \\
\text { namese Ministry of Social Affairs and the United Nations. }\end{array}$ \\
\hline 1970 & $\begin{array}{l}\text { - The Vietnam Army School of Social Work and the Buddhist Youth School for } \\
\text { Social Service established in Saigon. }\end{array}$ \\
\hline $\begin{array}{l}\text { Post American war } \\
(1975-1986)\end{array}$ & \\
\hline 1975 & $\begin{array}{l}\text { - Vietnam War ended. The Socialist Republic of Vietnam was established. All } \\
\text { social work activities in the South were terminated }\end{array}$ \\
\hline 1986 - present & \\
\hline 2010 & $\begin{array}{l}\text { - Decree } 32 \text { was issued by the Vietnamese government, laying foundations for } \\
\text { social work development in Vietnam between } 2010 \text { and } 2020 \text {. }\end{array}$ \\
\hline 2011 & $\begin{array}{l}\text { - The Vietnam Ministry of Health approved two National } 2011-2020 \text { programs to } \\
\text { develop (1) hospital social work, and (2) community-based mental health services. }\end{array}$ \\
\hline 2013 & - Association of Vocational Training \& Vocational Social Work was established. \\
\hline 2015 & $\begin{array}{l}\text { - Ordinance Specifying the Roles and Organization of Social Work Activities in } \\
\text { Hospital. Ordinance Specifying Job Codes and Title Standards for Social Work } \\
\text { Professionals. }\end{array}$ \\
\hline 2016 & $\begin{array}{l}\text { - The Prime Minister decided to select March } 25 \text { every year as Vietnam's social } \\
\text { work day. }\end{array}$ \\
\hline 2017 & $\begin{array}{l}\text { - The strategic plan for the development of Vietnam social work training 2017- } \\
2020 \text { was signed and issued by the Ministry of Labor, Invalids and Social Affairs }\end{array}$ \\
\hline
\end{tabular}

development of the scientific training - hightech. The industrial revolution 4.0 has created enormous pressure on Vietnam's social work sector to solve unemployment and underemployment, the rich-poor gap, social evils, and crimes tend to increase, there are concerns about loss of identity, assimilation of culture, and destruction of national culture. Especially challenges from the harshness of nature taking place in the early years of the new millennium such as epidemics, climate change, earthquakes, floods, etc.

Firstly, the challenge to training science and high technology level for professional social work. Vietnam needs to have a roadmap to train highly qualified cadres in science and technology, from scientific researchers, technology creators, product designers to those, 
who directly plan policies, social work managers and social services; requires the psychological changes, the lifestyles of all walks of life, change the organization and management of the system of government at all levels and branches. These are not easy issues, which really is a big challenge. While people's perceptions are still very limited to professional social work, the system of legal documents on the social work of the government is lacking, and weak is unable to keep up with the current process of professional social work. In particular, the investment in infrastructure for social work is too small, largely dependent on the state budget. In addition, the professional social work training program at universities in Vietnam has many limitations such as the time and theoretical training program is major, lacking or weak in practical training and organization for students to practice at the facilities; training content is far from reality, not suitable to the needs of Vietnamese society. Moreover, the quality of training and the fierce competition among universities now give rise to many big problems for society. Without overcoming these small challenges, in particular, the biggest challenge for Vietnam will be lagging far behind, compared to other countries in the Asia-Pacific region and the world.

There is debate about developing training professional social work in Vietnam relates to the understanding of the difference between 'educations' and 'training'. There is a lack of understanding about the importance of practice as a part of the educational process in Vietnam. This is reflected in the proportion of credits in the degree allocated to practicum, namely 10 out of a total of 210 (that is, just under 5\%) (Durst et al., 2006: 18). In this way, it could be said the challenges that are present in the developing Vietnamese social work education system reflect a widespread issue for social work around the world. In other respects, the social work curriculum in Vietnam is following the international standards of best practice as defined by the Global Standards for Social Work Education and Training (IASSW/IFSW, 2004). But social work is still developing in Vietnam, and there are relatively few practitioners with full university qualifications in the discipline (Richard Hugman et al., 2009).

Currently, Vietnamese science and technology products have been improved and renewed, but most of them still use the old technology, outdated. Technological innovation compared to the common ground is still slow. In the context of a difficult economy, the investment in research and technological innovation is very limited, leaving science and technology products lagging behind the world, reducing their competitiveness in this area. On the other hand, technological innovation is not simply replacing old systems with new ones, but also need to renovate both a management system as well as a high-quality workforce of social work. The Vietnam Science and Technology Development Strategy up to 2025 requires the rate of technological innovation to reach $15-20 \%$ per year, this means that after about 5 years of social work services, the social work management agency and Vietnamese businesses must innovate a generation of technology. In fact, this number is too high, that compared to the current development of Vietnam's professional social work, but on the other hand, it is considered too low for Vietnam's science and technology (Ngo Thanh Tu, 2018).

Secondly, the challenges of industrial revolution 4.0 in the process of developing Vietnamese social work in international integration. In the context, that Vietnam is deeply integrating into the world economy with the signing of large-scale free trade agreements such as: CPTPP Agreement; FTA with EU; FTA with Asia-Europe economic union... Access to the success of Industry 4.0 will create an effective tool to help Vietnam effectively participate in global value chains and accelerate the process of industrialization and modernization of the country. However, this process also brings many significant challenges in the development process. Especially the field of Vietnam socio-cultural in general and the process of professionalization of social work in Vietnam in particular.

1) The Industrial Revolution 4.0 poses challenges in building and perfecting the institutional system, policies and legal framework for the development of professional social work 
with the requirement to develop quickly, synchronously but be flexible to adapt and manage well all activities of professional social work. It poses a serious challenge for the Vietnamese government, as the social work sector is a completely new industry compared to other sectors. Therefore, building the institutional system, policies and legal framework to keep up the rapid integration process is not only a big challenge but also difficult to implement. Vietnam needs to have flexible, short-term and long-term development strategies, combining many resources to limit the current and weak challenges of mechanisms, policies and legal frameworks in the current reality.

2) The Industrial Revolution 4.0 also creates challenges in promoting the application of new technological achievements, to improve the management efficiency of state agencies in the process of developing professional social work. Currently, state management agencies are operating and managing the activities of social work in a traditional way and organization, this way depends on direct human activities. for example: social work practice training activities at universities often focus on surveys, manual investigation with quantitative results, very time consuming, the results are often not reliable.

3) Challenges in training, improving the qualifications and competencies of social workers, those who directly trained high-quality labor resources at universities, staff in the social management system in general and researchers and policymakers on social work management. The resources to invest in training high-quality cadres are mainly from the state budget. In addition, mechanisms and policies to encourage the staff, lecturers to improve professional social work expertise is limited and difficult to apply in practice. Moreover, the salary regime and other benefits for highly qualified social workers are not attractive enough compared to other fields such as the economic and other cultural. They are major challenges if the government does not have the evaluate and adjust appropriately.

4) The challenge of solving new social issues with the foundation of integrating many modern technologies will have an impact on almost all sectors of social life. Especially employment and labor, potentially disrupting the labor market balance, when automation (robots) dominates many fields, the unemployment in society will increase, especially a free and untrained workforce. Besides, the gap between poverty will increase, along with the occurrence of social evils and loss of social order and security.

5) Industrial Revolution 4.0 makes a big change in all areas of social life. According to many experts, it is developing exponentially rather than linear speed. Facing the drastic change of society due to the impact of the 4.0 industrial revolution, the government must make timely changes in all areas, of which professional social work development must be the most important factor (Dang Xuan Tam, 2018).

Thirdly, Challenges from nature and epidemics to professional social work development in the process of international integration. Climate change does not seem to be far off for all Vietnamese. It can be said that, researching and assessing climate change, the impacts of climate change as well as proposing solutions, strategies, and plans to cope with climate change have become global issues. As a country located in the region strongly affected by climate change, with a tropical monsoon climate and adjacent to the East Sea. Every year, Vietnam is affected by many natural disasters that are becoming more and more complicated and show signs of increasing. Climate change and sea-level rise have had devastating effects and are threatening the sustainable development of the country, especially the social work sector faces many major problems in social security.

Assessing the impact of climate change should be based on climate change assessment information, i.e. knowing how the climate has and will change. So far, there have been several climate change assessment results in the past and present, but still not comprehensive compared to actual needs, and assessing climate change in the future is still a big gap. With the viewpoint of recognizing the impacts of climate change in two aspects: the impact of slow change and the impact of extreme climate events, adaptation also needs appropriate strat- 
egies, roadmaps and solutions (Phan Van Tan, 2020).

From the challenges of climate change, the social work sector must address many of the social problems, such as employment, housing, potential risks of insecurity and social order. Especially, the process of professionalization of social work will be slow compared to other countries in the region and in the world.

Besides, Vietnam is also a country facing great challenges from epidemics, for example, the new strains (COVID-19). This is a great pressure on the economy as well as all sectors of Vietnamese society. Professional social work faces new challenges in addressing specific social issues such as: develop scenarios for disease control; find solutions to support people to fight epidemics and stabilize their lives; providing psychological counseling to care for overseas Vietnamese returning home to avoid epidemics, etc...

So far, many domestic and foreign research organizations have forecasted the impact of the COVID-19 pandemic on the Vietnamese economy. However, these forecasts are based on the epidemic situation from the beginning of March 2020, before Europe and the US have not been affected as hard as currently. Bloomberg forecast that Vietnam's growth will decrease by $0.4 \%$ (data to February), ADB believes that growth decreases by $0.5-1 \%$ and the bad scenario may decrease by $1.5 \%$ (Report on 10/03/2020). The Ministry of Planning and Investment forecasts that growth may decrease from 0.67 to $0.96 \%$, inflation in the range of $3.96 \%-4.86 \%$, exports decreased by $21 \%$, imports by $16 \%$, agriculture by $0.11 \%$; industry decreased by $0.24 \%$; service sector decreased by $0.32 \%$ (February, 4 and February, 10 reports). The State Bank of Vietnam forecasts that Vietnam's inflation will fluctuate around 4.5\% +/- 0.4\% (Report on March, 12). The research team that conducted the Vietnam Economic University's 2019 Vietnam Economic Assessment publication forecast growth to decrease from 0.6 to $0.8 \%$ (data to March 7). In the latest report (March 31, 2020), the World Bank predicts that Vietnam's economy in 2020 will be about $1.5 \%$ to $4.9 \%$ (National Economics University Report, 2020).
Many synchronized and flexible solutions from the government and related ministries. In particular, the Ministry of Labor, War Invalids and Social Affairs has been implementing and managing social work to minimize risks.

Firstly, the solution group develops and trains high-quality human resources and technology. The government concentrated the available resources; enhance socialization to attract financial resources from international organizations, from domestic and foreign private investment in the development of training and applying technologies in the field of social work. In particular, the government continues to adjust the policy mechanisms and training programs for universities, improve the quality of training and application of technology in practice, and specific characteristics of the social work sector (Dam Huu Dac, 2016).

Secondly, continuing to invest in infrastructure, human resources, gradually meet and address the challenges of strong industrial revolution 4.0, which is creating great pressure on professional social work in Vietnam. In addition, the government has had to adjust the operating and administrative management for the professional social work sector, for example: shifting from traditional management to automation, maximizing the application of technological equipment to liberate human labor directly in solving modern social problems.

Thirdly, professional social work has been actively involved with other organizations to propagate, mobilize all people to raise awareness of environmental protection, building a healthy living environment. Actively participate in policies and solutions of the government to reduce and repel epidemics, for example, mandatory medical declaration for each citizen daily, seriously implementing social isolation, in an emergency when an epidemic breaks out. Besides, the implementation of market price stabilization, the cost of living of the people. Activities to support the socially vulnerable groups from social work services have contributed to helping Vietnam stabilize society, control diseases and limit negative impacts from climate change. 


\section{Vision and Orientation Develop the Social Work Professionals in the International Integration Process}

In order for social work to become a professional and to operate effectively from now to 2025 and a vision to 2030 , Vietnam needs to focus all resources to well perform some of the following urgent tasks.

Firstly, continue to promote media activities, education, social mobilization, to raise awareness of the people and the whole society about the role, importance, as well as the strategic significance of the development of professional social work sector in the cause of economic development - the society in Vietnam. That is because of the sustainable development of the country and the survival of the people of Vietnam; we cannot solve complex social problems between person to person with inherent experience, with the pure political will but with a kind heart and using the scientific approach of social work, with the professional tools of social work. It is the most fundamental and sustainable way to solve.

Secondly, promoting scientific research and advocating for the development of many social policies to formulate the legal framework, mechanism, and policy enacted a separate law next time on professional social work in Vietnam. The recognition of the law is especially important for training, developing human resources and arranging the use of professionally and semi-professionally trained staff in this field in Vietnam.

Thirdly, forming a chain of national social work services to all objects in society, with diverse and flexible criteria in the type of service. Expand social work activities to many fields in society such as police, court, military, hospital, school, etc. To develop professional social work to 2025 and vision to 2030 comprehensive international integration. In particular, focuses on training high-quality human resources in social work occupations to meet the needs of labor in rural and remote areas.

Fourthly, the orientation of developing professional social work in Vietnam from now to 2025 follows the development of roadmap from vague to clear, change from amateur to professional with ethical standards and high professional skills, continues to inherit the world's professional social work knowledge and promotes the tradition of solidarity and mutual love of the Vietnamese people. According to this development roadmap, non-professional activities will be gradually eliminated, and replaced by diversified and flexible activities with high professionalism. At the same time, from now to 2025 , we will see the strong participation of the State subjects in the development of social work careers in Vietnam, so that Vietnam will quickly join in the countries with developing social work sector in the Asia-Pacific region and the world.

Finally, strengthen international cooperation on the development of the professional social work, both multilateral, bilateral and non-governmental, both multilateral, bilateral, and non-governmental, through these activities to accumulate experience, knowledge and mobilize additional resources for career development in Vietnam. Besides that, experience, and investment resources are limited, the expansion of international cooperation to share and learn from experience is the shortest and most effective way (Nguyen Hai Huu, 2012).

\section{Conclusion}

Although social work as a profession is new in Vietnam, the country is quickly adopting ideas about practice standards, a code of ethics, licensure, accreditation and other contemporary characteristics of a bona fide profession. This coincides with the globalization of the social work profession and social work education, a process that often draws on models based on the institutions, perspectives, values, and particular histories of Western societies. It is clear that leaders in Vietnam are keen on making social work an effective and valued profession. At the same time, there remains an urgent challenge to incorporate from this tradition relevant knowledge and insight while steering the profession toward the unique needs of Vietnam, consistent with its own cultural heritage and socio-political context. Currently, the Government and related ministries have implemented several simultaneous and 
flexible solutions to adjust it such as completing policy institutions, financial investment, human resources and expanding international cooperation. With multiple synchronization of solutions being implemented, professional Social Work in Vietnam will meet the needs of society and will contribute to stabilizing socio- politics and developing national capacity for international integration.

\section{Data Availability}

The data that support the findings of this study are available from the corresponding author upon reasonable request.

\section{References}

Brydon, K., \& Lawihin, D. (2016). Melanesian visions? Some preliminary thoughts about social work education and practice in Papua New Guinea. In International Social Work, 59(2), 192-204. https://doi. org/10.1177/0020872813515012

Dam Huu Dac (2016). Building and developing professional social work careers in Vietnam. Social work career development orientation. In Communist magazine.

Dang Xuan Tam (2018). The dynamics of the 4th industrial revolution to the world economy, opportunities and challenges in the process of international economic integration of Vietnam. Vietnam International Economic Integration Forum 2018.

Hugman, R., Durst, D., Le Hong, L., Nguyen, T.T.L., \& Nguyen, T.H. (2009). Developing Social Work in Vietnam: Issues in Professional Education. In Social Work Education, 28(2), 177-189. https://doi. org $/ 10.1080 / 02615470802243087$

Huong Nguyen, Trang Thu Nguyen \& Naomi Farber (2017). Vision, Challenges, and Solutions in the Development of Professional Social Work in Vietnam: Perceptions of Key Stakeholders. Published by Redfame Publishing. In International Journal of Social Science Studies, 5 (3), 22-26.

Labor Science Society - Vietnam Society (2010). Assessment of the status of Social Security in the 2001-2010 period. Hanoi. P. 34-35.

Nguyen, V.H. (2014). Reviewing the implementation of Project 32 on developing social work profession between 2010 and 2014, in Reality, and integration of social work development in Vietnam, Hanoi, Thanh Nien Publishing House.

Ngo Thanh Tu (2018). Opportunities and challenges of Vietnam's science and technology in the context of globalization today. Publisher: Van lang University. P. 23-25.

National Economics University (2020). The report assesses the impact of COVID-19 on the Vietnamese economy and policy recommendations. Publisher: Hanoi National University. P. 23-25.

Nguyen Hai Huu (2012). To make social work become a professional profession in Vietnam. Ministry of Labor, Invalids and Social Affairs.

Oanh, N.T. (2002). Historical development and characteristics of social work in today's Vietnam. In International Journal of Social Welfare, 11(1), 84-91. https://doi.org/10.1111/1468-2397.00199

Phan Van Tan (2020). Vietnam Climate Change: Issues to be addressed. In Scientific publications and development of the magazine Scientific American.

Richard Hugman, Douglas Durst, Le Hong Loan, Nguyen Thi Thai Lan \& Nguyen Thuy Hong (2009). Developing Social Work in Vietnam: Issues in Professional Education, Social Work Education. In The International Journal, 28 (2), 177-189. 